\title{
Taxonomic features of fruits and seeds of Nymphaea and Nuphar taxa of the Southern Baltic region
}

\author{
Karol Latowski', Cezary Toma ${ }^{2}$, Magdalena Dąbrowska ${ }^{3,4}$, Egita Zviedre $^{5}$ \\ ${ }^{1}$ Department of Plant Taxonomy, Institute of Environmental Biology, Adam Mickiewicz University, Umultowska 89, 61-614 Poznań, \\ Poland, e-mail: latowski@amu.edu.pl \\ ${ }^{2}$ Department of Carpology, Institute of Environmental Biology, Faculty of Natural Science, Kazimierz Wielki University, Ossolińskich \\ 12, 85-093 Bydgoszcz, Poland, e-mail: cezarytoma@poczta.onet.pl (corresponding author) \\ ${ }^{3}$ Department of Botany and Nature Protection, University of Warmia and Mazury, Plac Łódzki 1, 10-727 Olsztyn, Poland \\ ${ }^{4}$ Institute of Botany, Jagiellonian University, Kopernika 27, 31-501 Kraków, Poland, e-mail: m.a.dabrowska@uj.edu.pl \\ ${ }^{5}$ Department of Botany and Ecology, University of Latvia, Kronvalda bulv. 4, Riga, Latvia, e-mail: egita.zviedre@dabasmuzejs.gov.lv
}

\begin{abstract}
Research was carried out on fruits and seeds of Nymphaea and Nuphar taxa collected from Poland, Latvia and Estonia. The aim of the research was to establish diagnostic features which could enable identification of the examined taxa on the basis of the fruit and seed structure and creating a key to identify them. The examined organs were observed through an optic microscope and scanning electron microscope (SEM). New diagnostic features were discovered: spotting of fresh pericarp, the range of the fruit shape coefficient, the colour of the rays in the fruit stigma disc, the thickness of the seed testa, ribs in the seeds, and occurrence of the "puzzle shaped" cells on the surface of the testa. The discovered features were used in the taxonomic characteristics.
\end{abstract}

Key words: lake, seed, fruit, carpology, Nuphar, Nymphaea, taxonomy, anatomy, morphology

\section{Introduction}

The examined Nymphaea and Nuphar taxa represent the Nymphaeacea family that had earlier been investigated in terms of the anatomy of spermoderm (Melikian 1964), the development of the embryo in selected species of Nymphaea (Valceva and Savics 1965), the structure of Nymphaeacea ovule and seeds (Takhtazhian 1988) and the development of the integument, micropyle structure, morphology and anatomy of the stigma of Nuphar (Zhou and Fu 2008). Schneider and Williamson (1993) presented a research summary on the Nymphaceae family. Nuphar is a holoarctic taxon (Beal 1956) and comprises 8 species and three hybrids (GRIN 2014a) while Nymphaea is cosmopolitan comprising about 54 species (GRIN 2014b).

Despite existing studies on the subject of taxonomy of Nymphaea and Nuphar (Moseley 1961a, 1965b, 1971c; Casper and Krausch 1980; Padgett 2003a, 2007b; Conard 1905; Wiersema 1988; Yamada et al. 2001; Dkhar et al. 2013), they lack detailed reports on the fruit and seed structures of Nymphaea alba, N. candida, Nuphar lutea and N. pumila. Identification of these species, especially N. candida, may be troublesome. This boreal species reported in northern Poland so far (Zając and Zając 2001), has also recently been found in many places in the southern regions of Poland (Nowak et al. 2010). Therefore, research on the fruits and seeds of the taxa and a scientific description of the carpological key have been undertaken, which will make their identification easier. The seed features are some of the most enduring and they are retained even in fossil material. Discovering new features will make it possible to use them in the identification of paleobotanical materials.

The aim of the research is to distinguish and characterize the structural features of the fruit and seeds and, on their bases, to create a dichotomous key to identify them. 


\section{Materials and methods}

The research materials are ripe fruits of N. alba, $N$. candida, $N$. lutea and $N$. pumila collected from the areas of Poland, Estonia and Latvia. A list of collection sites for all species is presented in Table 1 .

The collected fruits were dried, then examined with the use of Leica M200 stereo microscope and SEM microscope model EVO40 of Carl Zeiss. The following morphological features of fruit and seeds were examined: the formation of the surface, the shape and size, the nature of the stigma disc, the number of seeds in a fruit; the shape, size and colour of the seeds, ribbing in the seeds, micromorphology of the testa surface. The quantitative features were measured
30 times. The measurements were taken with the help of image analyser Met-Ilo8. Altogether 180 seeds and 30 fruits were examined.

The range of sizes and arithmetic mean are presented in the results. The surface and circumference of the fruit or seed represent the surface of the orthographic projection of the fruit or seed. The shape coefficient (abbreviated WK henceforth) determines the shape of the fruit and seeds. It ranges from 0 to 1 . Perfectly round objects are 1 while flat ones are 0 . The term "puzzle shaped" cell is used in the texts to refer to those with deeply undulated sinused walls. These are the cells that make up the testa in the Nymphaea seeds resembling a puzzle piece where each has fingershaped or branched papillae.

Table1. Localities of species of Nuphar and Nymphaea genus for seed and fruit research

\begin{tabular}{llll}
\hline No. & \multicolumn{1}{c}{ Taxa } & \multicolumn{1}{c}{ Water body: Country, City/Town } & \multicolumn{1}{c}{ Collectors and sampling date } \\
\hline 1 & Nuphar lutea & Pond: Poland, Katowice (Dolina Trzech Stawów) & Toma C., 9 September 2010 \\
\hline 2 & Nuphar pumila & Small lake: Poland, Sępólno Małe near Biały Bór & Toma C., 18. September 2011 \\
\hline 3 & Nymphaea alba & Lake Średnie: Poland, Wołcza Mała & Toma C., 18 September 2012 \\
\hline 5 & Nymphaea candida & Lake Zgniłek: Poland, Olsztyn & Dąbrowska M., 3 September 2012 \\
\hline 6 & Nymphaea candida & Lake Köstrejärv: Estonia, Lüllemäe & Freiberg L., Mäemets H., 22 September 2012 \\
\hline
\end{tabular}

\section{Results}

\section{Nuphar lutea (L.) Sibth. \& Sm (Figs 1-3)}

Fresh fruit is green, smooth, and shiny while dried fruit is matt; the pericarp adheres closely to the seeds, which make a small bulge on its surface. Features of fruits: 1. Fruit colour: earthy green; 2 . Dimensions of dry fruit: diameter $33.5 \mathrm{~mm}(28-40 \mathrm{~mm})$, length $46.0 \mathrm{~mm}(38-54 \mathrm{~mm})$; 3. Pigmentation of fresh pericarp: absence; 4 . Shape and dimensions of stigma disc: round, diameter $13.5 \mathrm{~mm}$ (12-15 $\mathrm{mm}$ ), 17-19 rays; 5 . Average number of seeds in fruit: 200; 6. Area of fruit: $969.78 \mathrm{~mm}^{2}\left(866.24-1073.33 \mathrm{~mm}^{2}\right)$; 7. Circumference of fruit: $126.7 \mathrm{~mm}(116.54-136.86 \mathrm{~mm}) ; 8$. The shape of a slightly flattened sphere with elevated stigma disc, $\mathrm{WK}=0.87$ (0.80-0.95).

Features of seeds: 1. Colour of seed: yellow; 2 . Dimensions of seed: length $4.25 \mathrm{~mm}(3.75-4.8 \mathrm{~mm})$, width $2.8 \mathrm{~mm}(2.3-3.3 \mathrm{~mm})$; 3 . Area of seed: $9.5 \mathrm{~mm}^{2}$ $\left(6.59-12.2 \mathrm{~mm}^{2}\right)$; 4. Circumference of seed: $11.5 \mathrm{~mm}$ (9.9-13.2 mm); 5. Seed slightly elongated, WK $=0.89$ (0.88-0.90); 6. Rib occurrence: absence, hilum pear shape; 7. Thickness of testa: 150-200 $\mu \mathrm{m}$; 8 . SEM micromorphology of the testa surface: regular cell pat- tern, hexagonal testa cells, more or less isodiametric, smooth anticlinal walls, slightly elevated, wide and flat, the wall thickness 11-15 $\mu \mathrm{m}$, periclinal walls slightly concave, secondary sculpture is made by irregular structures on the surface of the periclinal walls with diameter $2-3 \mu \mathrm{m}$. The testa cells are $40 \times 70 \mu \mathrm{m}$.

\section{Nuphar pumila (Timm) DC. (Figs 4-6)}

Fresh fruit is green, smooth, and shiny while dried fruit is matt. The pericarp of dried fruit adheres closely to the seeds, which are visible from the outside. Features of fruit: 1. Fruit colour: brown; 2. Dimensions of dry fruit: diameter $10.0 \mathrm{~mm}(8-12 \mathrm{~mm})$, length 19.0 $\mathrm{mm}$ (13-25 mm); 3. Pigmentation of fresh pericarp: absence; 4. Shape and dimensions of stigma disc: lobed, 4-5 mm, 9-10 rays, brownish red rays slightly elevated over the surface of stigma disc; 5 . Average number of seeds in fruit: 70; 6 . Area of fruit: 171.27 $\mathrm{mm}^{2}$ (136.18-206.36 $\left.\mathrm{mm}^{2}\right)$; 7. Circumference of fruit: $63.18 \mathrm{~mm}(55.71-70.65 \mathrm{~mm}) ; 8$. Pear shape of fruit, $\mathrm{WK}=0.56(0.52-0.60)$.

Features of seeds: 1 . Seed colour: green; 2 . Dimensions of seed: length $3.0 \mathrm{~mm}(2.7-3.3 \mathrm{~mm})$, width $1.65 \mathrm{~mm}(1.50-1.80 \mathrm{~mm}) ; 3$. Area of seed: $3.77 \mathrm{~mm}^{2}$ (3.00-4.55 mm $\left.\mathrm{m}^{2}\right)$; 4. Circumference of seed: $7.88 \mathrm{~mm}$ 
(7.34-8.43 mm); 5. Seed slightly elongated, $\mathrm{WK}=0.76$ (0.72-0.80); 6. Rib occurrence: one rib, 8 -shape hilum; 7. Thickness of testa: $50 \mu \mathrm{m}$; 8 . SEM micromorphology of the testa surface: irregular cell pattern, 6 or 7-walled or oval cells, anticlinal walls slightly elevated, smooth, periclinal walls are slightly lowered. Secondary sculpture of periclinal walls is made of small bulges of $5 \mu \mathrm{m}$ in diameter. Testa cells are $17 \times 35 \mu \mathrm{m}, 20 \times 30 \mu \mathrm{m}$, $30 \times 30 \mu \mathrm{m}$.

\section{Nymphaea alba L. (Figs 7-9)}

Irregular traces of the perianth visible on the outside of the fruit. Features of fruits: 1. Colour of fruit: brown; 2. Dimensions of dry fruit: length 16.55 $\mathrm{mm}$ (15.88-17.23 mm), diameter $17.33 \mathrm{~mm}$ (15.54$19.12 \mathrm{~mm}) ; 3$. Pigmentation of fresh pericarp: present; 4. Disc of stigma: round without a stalk, diameter 10$11 \mathrm{~mm}$, flat rays in stigma disc, $16-18$ rays; 5 . Number of seeds in fruit: 750; 6. Area of fruit: $219.12 \mathrm{~mm}^{2}$ (196.66-241.59 $\left.\mathrm{mm}^{2}\right)$; 7. Circumference of fruit: 57.17 $\mathrm{mm}(56.05-58.29 \mathrm{~mm}) ; 8$. Fruit shape spherical, $\mathrm{WK}=$ $0.84(0.79-0.89)$.

Features of seeds: 1. Colour of seed: black in mature seeds and pink in young seeds; 2 . Dimensions of seed: length $2.52 \mathrm{~mm}(2.31-2.74 \mathrm{~mm})$, diameter 1.36 $\mathrm{mm}$ (1.21-1.52 mm); 3. Area of seed: $2.70 \mathrm{~mm}^{2}(2.20$ $\left.3.20 \mathrm{~mm}^{2}\right)$; 4. Circumference of seed: $6.90 \mathrm{~mm}(6.70$ $7.11 \mathrm{~mm}) ; 5$. The shape oval flattened on both sides, $\mathrm{WK}=0.73$ (0.61-0.85); 6. Rib occurrence: present, 8-shaped hilum; 7. Thickness of testa: $90-100 \mu \mathrm{m} ; 8$. SEM micromorphology of the testa surface: regular cell pattern, anticlinal cell walls concave, periclinal wall cells slightly convex, smooth cells of the "puzzle" type with 12 papillae, 4 of the papillae are dichotomously branched, cell size $63 \times 148 \mu \mathrm{m}$, the middle part of the testa cells up to the edge of the papillae $20 \times 50 \mu \mathrm{m}$. The size of the unbranched papillae $4-11 \mu \mathrm{m}$.

\section{Nymphaea candida J.PresI \& C. Presl (Figs 10-12)}

Fruit similar to N. alba, with irregular traces of the perianth visible on the outside of the fruit. Features of fruits: 1 . Colour of fruit: brown; 2. Dimensions of dry fruit: length $21.89 \mathrm{~mm}(17.15-26.63 \mathrm{~mm})$, diameter $21.01 \mathrm{~mm}$ (18.34-23.69 mm); 3. Pigmentation of fresh pericarp: present; 4 . Stigma disc of the fruit: round without a stalk, diameter $8-10 \mathrm{~mm}, 12-14$ rays; 5. Number of seeds in fruit: $720 ; 6$. Area of fruit: 402.41 $\mathrm{mm}^{2}$ (286.45-518.37 $\left.\mathrm{mm}^{2}\right)$; 7. Circumference of fruit: $75.50 \mathrm{~mm}(63.50-87.50 \mathrm{~mm}) ;$ 8. Fruit shape spherical, $\mathrm{WK}=0.86(0.83-0.89)$.

Features of seeds: 1 . Colour of seed: grey; 2 . Dimensions of seed: length $2.99 \mathrm{~mm}(2.90-3.09 \mathrm{~mm})$, diameter $1.52 \mathrm{~mm}(1.38-1.66 \mathrm{~mm})$; 3. Area of seed: 3.68 $\mathrm{mm}^{2}$ (3.25-4.12 $\left.\mathrm{mm}^{2}\right)$; 4. Circumference of seed: 7.61 $\mathrm{mm}(7.13-8.10 \mathrm{~mm})$; 5 . Seed shape spherical, WK = 0.80 (0.79- 0.82); 6. Rib occurrence: absent; 7. Thickness of testa: $97-100 \mu \mathrm{m} ; 8$. SEM micromorphology of the testa surface: regular cell pattern, anticlinal cell walls slightly concave, periclinal wall cells slightly convex, smooth, cells of the "puzzle" type with 12 papillae, 5-6 of which are dichotomously branched, the cell size $104 \times 130 \mu \mathrm{m}, 108 \times 130 \mu \mathrm{m}$, papillae unbranched sometimes occur along the long axis of the cell, and sometimes along the transverse axis of the cell. The size of the cell without papillae is $30 \times 70 \mu \mathrm{m}, 40 \times 50 \mu \mathrm{m}$. The width of the unbranched papillae is $4-13 \mu \mathrm{m}$.

The key to identify taxa on the basis of the characteristics of the fruit structure:

1. Fruit smooth with a stigma disc on a stalk, fresh pericarp without pigmentation Nuphar 1a. Fruit with traces of the perianth with a stigma disc without a stalk, fresh pericarp with pigmentation.....Nymphaea 2. Diameter of disc $12-15 \mathrm{~mm}, \mathrm{WK}$ of fruit 0.87 ....... Nuphar lutea

2a. Diameter of disc $4-5 \mathrm{~mm}$, WK of fruit 0.56 .......... Nuphar pumila 3. Number of rays $16-18$. Nymphaea alba 3a. Number of rays $12-14$ Nymphaea candida

The key to identify taxa on the basis of the seed structure:

1. Seed yellow or greenish and yellow, length of seed 4-5mm, thickness of testa 150-200 $\mu \mathrm{m}$.............Nuphar lutea 1a. Seed of different colour, length of seed 2-3 mm, thickness of testa 50-100 $\mu$ m..........................Nuphar pumila,

2. Seed with rib.

2a. Seed without rib.

3. Testa of seed with puzzle-shaped cells.

3a. Testa of seed without puzzle-shaped cells
Nymphaea alba, Nymphaea candida .Nuphar pumila, Nymphaea alba ..Nymphaea candida .Nymphaea alba .Nuphar pumila 

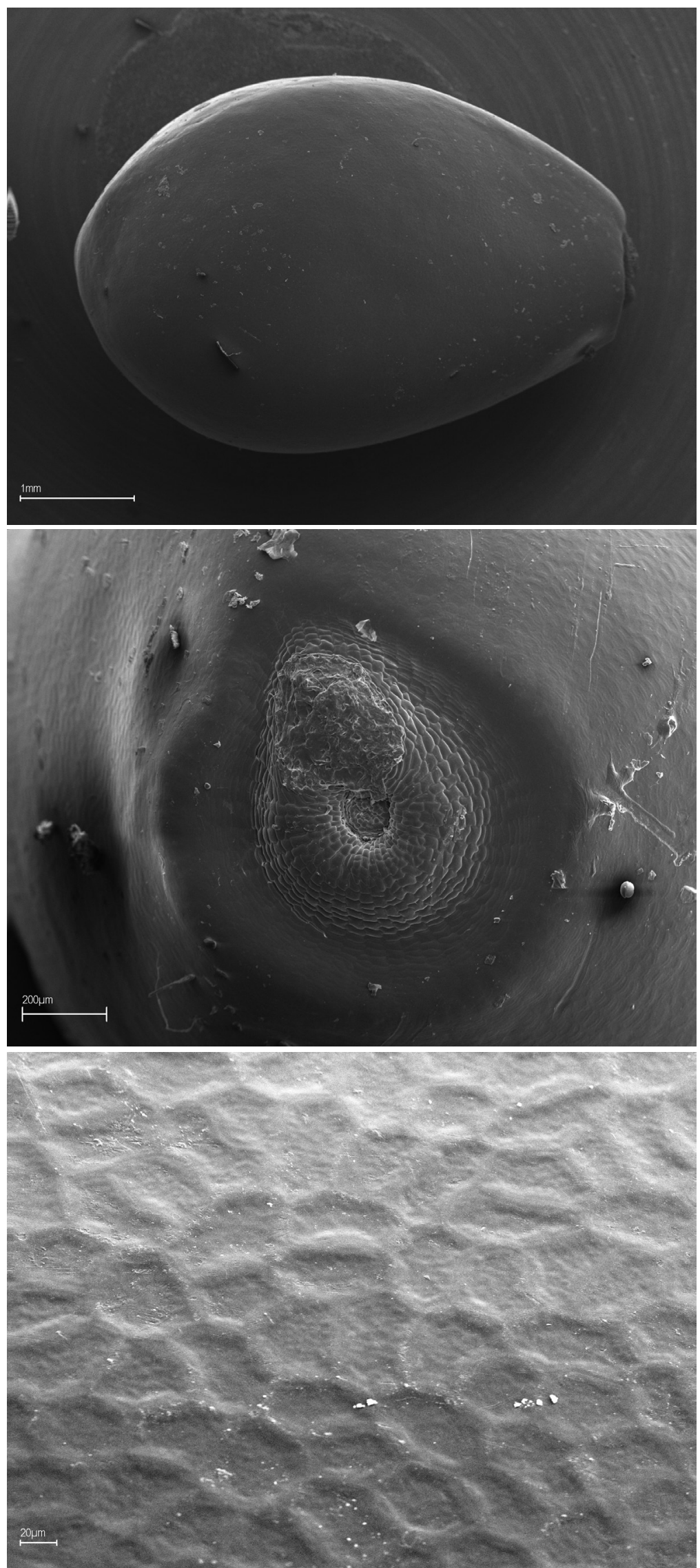

Fig.1. Nuphar lutea full view of seed

Fig.2. Nuphar lutea micropyle - hilum complex

Fig.3. Nuphar lutea cell pattern of testa seed 

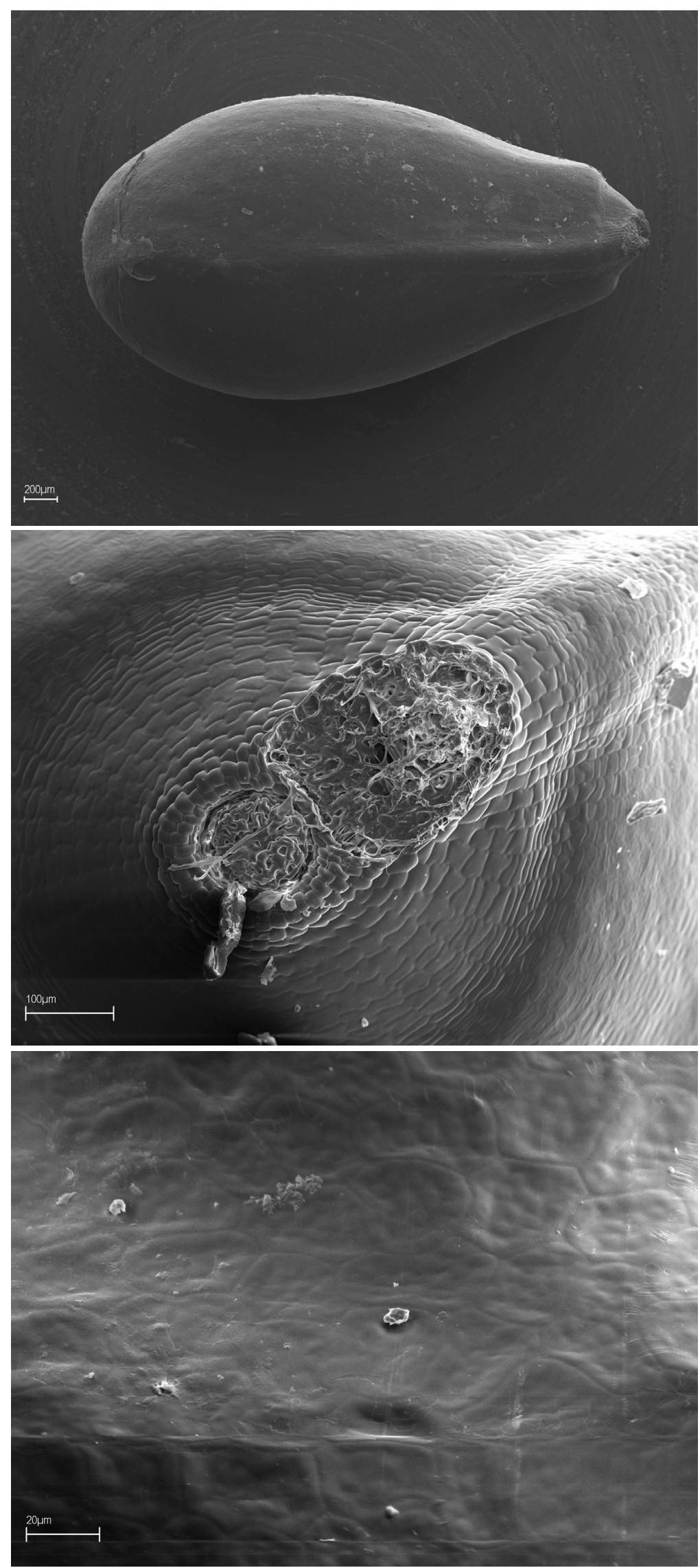

Fig.4. Nuphar pumila full view of seed

Fig.5. Nuphar pumila micropyle - hilum complex

Fig.6. Nuphar pumila cell pattern of testa seed 

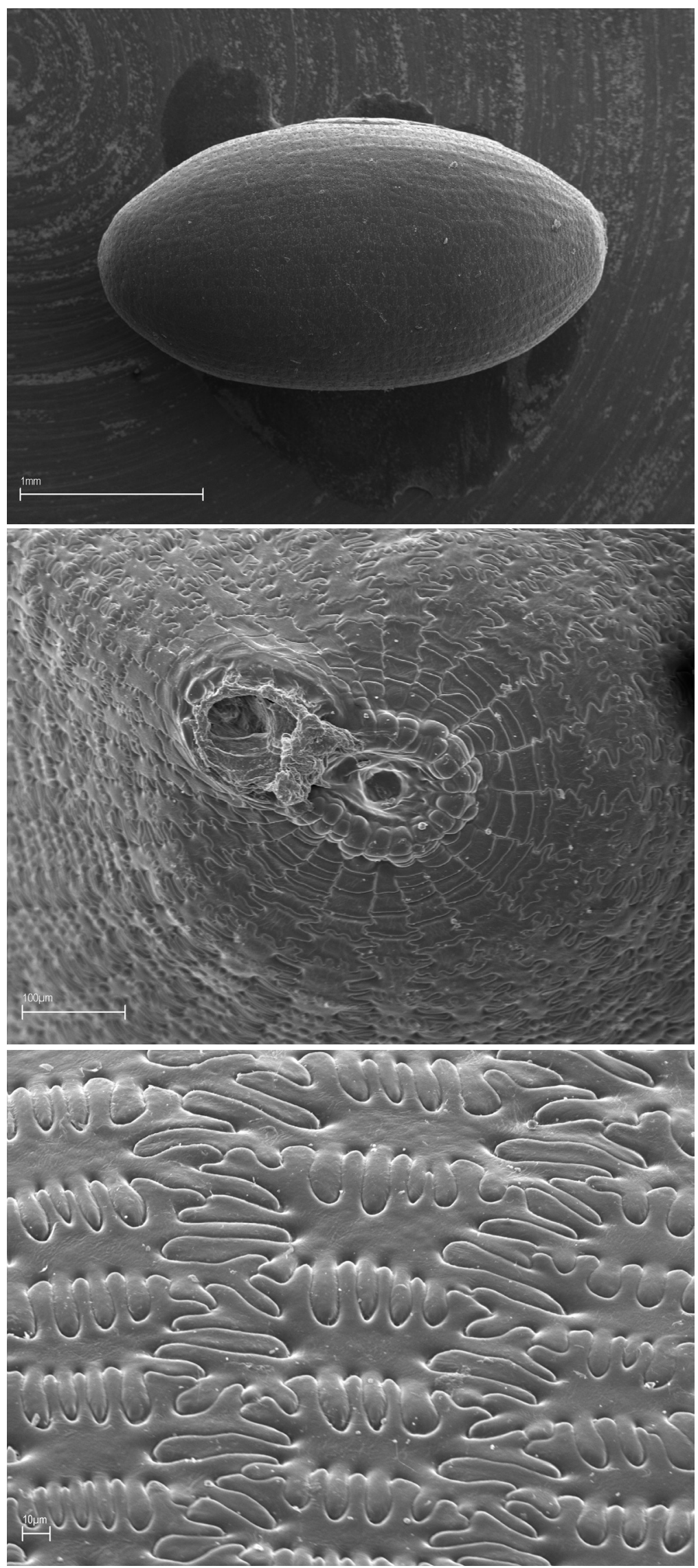

Fig. 7. Nymphaea alba full view of seed

Fig. 8. Nymphaea alba micropyle hilum complex

Fig. 9. Nymphaea alba cell pattern of testa seed 

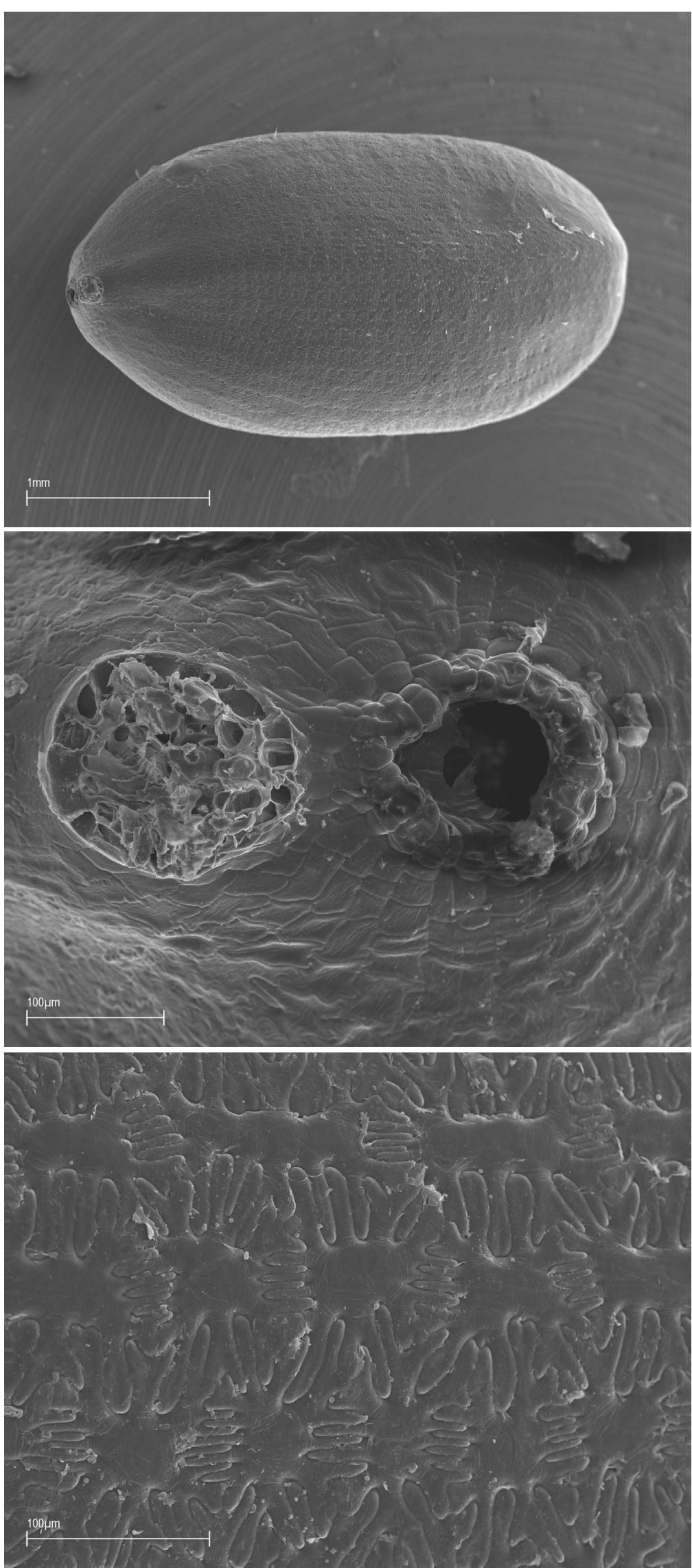

Fig.10. Nymphaea candida full view of seed

Fig.11. Nymphaea candida micropyle - hilum complex

Fig.12. Nymphaea candida cell pattern of testa seed 


\section{Discussion}

The basic data concerning the structure of Nympheaceae seeds and fruits in Europe are presented by Tutin and Webb (2010). The present research confirms the occurrence of 16-18 rays and 2-3 $\mathrm{mm}$ long seeds in Nymphaea alba, which falls within the margin given by Tutin and Webb (2010), stigma more or less flat, with $14-20$ rays, and seeds $2-3 \mathrm{~mm}$. The occurrence of 12-14 rays and seeds 2-3mm long was also confirmed in $N$. candida. The obtained result falls within the margin given by Tutin and Webb (2010) for concave stigma and the number of 6-14 rays as well as seeds of 3-5 mm long. However, the material did not include seeds falling into the higher margin given by Tutin and Webb (2010). It was stated that in Nuphar lutea there are 17-19 rays and seeds of 3-5 mm, which is in accordance with Tutin and Webb (2010) who report the features of the stigma disc, 15-20 rays, not quite reaching its margin and the length of the seeds of $5 \mathrm{~mm}$. However, in Nuphar pumila, 9-10 rays were found and the length of seeds of $2.5-3.5 \mathrm{~mm}$, which is also in accordance with Tutin and Webb (2010), who report the disc of the stigma as lobed, rays 8-10 reaching its margin and the seed length of $4.0 \mathrm{~mm}$. The rays in the Baltic region seeds of Nuphar pumila are slightly convex compared with rays of the seeds of Nymphaea and they are brownish red.

In the case of Nymphaea alba from the area of Great Britain, the number of seeds in one fruit is known to range from 500 to 1700 (Heslop-Harrison 1955) and is the same as the average number of seeds in this taxon in the Baltic region. Heslop-Harrison (1955) reported the dark olive green colour of Nymphaea alba seeds which differs from the colour of this taxon in the Baltic region, where the mature ones are black and the young ones are pink. Heslop-Harrison's study also describes their smooth surface, however does not include the description of the cell shape, which is typically "puzzle" like in this taxon in the Baltic region. The length of the British seeds in N. alba ranges from 2-5 $\mathrm{mm}$, whereas the Baltic ones are 2-3 $\mathrm{mm}$ long.

The reported diameters of Nuphar lutea of 3.8$5.4 \mathrm{~mm}$ long and 2.8-4.0 wide fall within the margin given by Padgett (2007) according to whom they are 2.6-4.5 mm long, and 1.9-3.4 $\mathrm{mm}$ wide. The diameter of the disc in N. lutea is $12-15 \mathrm{~mm}$ and also falls within the margin of 7-19 mm given by Padgett (2007). However, the diameter of the disc in N. pumila ranges from
4-5 $\mathrm{mm}$ and is in accordance with the one (4.0-7.5 $\mathrm{mm}$ ) given by Padgett (2007). However, Padgett (2007) did not give the width or the length of $N$. pumila seed in his key. The only features used in Padgett's key to identify Nuphar lutea and Nuphar pumila are diameter and shape of the disc, width and length of fruit and a description of the fruit shape. Adding features of $\mathrm{Nu}$ phar fruit and seeds such as changes in the seed shape coefficient of Nuphar, the colour of the rays in Nuphar stigma discs, the thickness of Nuphar seed testa and occurrence of ribs in Nuphar pumila seeds observed in this study made it possible to create the key to identify Nuphar and Nymphaea taxa based on fruit and seed features. In the case of Nymphaea fruit and seeds, the diagnostic features not used before are brown pigmentation of fresh Nymphaea perianth, changes in the seed shape coefficient of Nymphaea, the thickness of Nymphaea seed testa, occurrence of ribs in Nymphaea alba seeds, and occurrence of the "puzzle" type of cells on the surface of Nymphaea seed testa.

While discussing the structure of Nymphaea and Nuphar seeds and fruit, it is worth mentioning the differences in the ripening process of fruits; $\mathrm{Nu}$ phar fruits remain on the surface of the water whereas Nymphaea fruit go under water immediately after the flower closes.

The image analyser is very effective in carpological research. However, seeds must be carefully positioned while photographs are being taken. The seeds which have ribs produced different results for the surface, circumference and WK depending whether they were photographed on their ventral side or on the dorsal side. Another thing which may disturb the result of the analyser is the use of SEM pictures taken from an acute angle while tilting the table with seeds in SEM. The result obtained may also differ from the result of a photo taken perpendicularly to the testa surface.

In conclusion, new diagnostic features of fruit and seeds were discovered: pigmentation of fresh pericarp, changes in the shape coefficient of fruit, the colour of the rays in stigma discs, the thickness of the testa, occurrence of ribs in the seeds, occurrence of the "puzzle" type of cells on the testa surface. A key to identify the taxa was created on the basis of the fruit and seed features. Learning about the new features of Nymphaea alba and N. candida seeds will enable researchers to resolve any doubts about identification of those two taxa after blooming. 


\section{Acknowledgements}

We would like to thank Dr Helle Mäemets from Centre for Limnology, Institute of Agricultural and Environmental Sciences, Estonian University of Life Sciences, Tartu, Estonia for sending seeds for research.

\section{References}

Beal E.O., 1956, Taxonomic revision of the genus Nuphar Sm. of North America and Europe, J. Elisha Mitchell Sci. Soc. 72: 317-346.

Casper J., Krausch H.D., 1980, Pteridophyta und Anthophyta. Band 23. Teil 1, [in:] Pascher A. (ed.) Süßwasserflora von Mitteleuropa [Freshwater Flora of Europe],Gustav Fisher Verlag, Jena, p.542.

Conard H.S., 1905, The waterlilies: a monograph of the genus Nymphaea, Publ. Carnegie Inst. Wash. 4:1-279.

Dkhar J., Kumaria S., Rama Rao S., Tandon P., 2013, New insights into character evolution, hybridization and diversity of Indian Nymphaea (Nymphaeaceae): evidence from molecular and morphological data, Syst. Biodivers. 11(1): 777-786.

[GRIN] Germplasm Resources Information Network, 2014a, GRIN Taxonomy for Plants. Genus: Nuphar Sm. Retrived from http://www.ars-grin.gov/cgi-bin/npgs/ html/genus.pl?8319 on 4th January 2014.

[GRIN] Germplasm Resources Information Network, 2014b, GRIN Taxonomy for Plants. Genus: Nymphaea L. Retrived from http://www.ars-grin.gov/cgi-bin/npgs/ html/genus.pl?8329 on 4th January 2014.

Heslop-Harrison Y., 1955, Nymphaea L., J. Ecol. 43(2): 719734.

Melikian A.P., 1964, Sravnitelnaia anatomia spermodermy nekotorykh predstavitelei semeistva Nymphaeaceae [Comparative anatomy of the spermoderma of some representatives of the family Nymphaeaceae], Botan. Zhurnal 49(3): 432-436 (in Russian).

Moseley M.F., 1961, Morphological studies of the Nymphaeaceae. II. The flowers of Nymphaea, Bot. Gaz. 122: 233-259.

Moseley M.F., 1965, Morphological studies of the Nymphaeaceae. III, The floral anatomy of Nuphar, Phytomorphology 15:54-84.

Moseley M.F., 1971, Morphological studies of the Nymphaeaceae, VI. Development of the flower of Nuphar, Phytomorphology 21:253-283.
Nowak A., Nobis M., Dajdok Z., Zalewska-Gałosz J., Nowak S., Nobis A., Czerniawska-Kusza I., Kozak M., Stebel A., Bula R., Sugier P., Szlachetka A., Bena W., Trojecka A., Piwowarczyk R., Adamiec A., Krawczyk R., 2010, Revision of Nymphaea candida range - new data on the distribution and habitat preferences of the species in Southern Poland, Acta Soc. Bot. Poloniae 79(4): 333-350.

Padgett D.J., 2003, Phenetic studies in Nuphar Sm. (Nymphaeaceae): variation in sect. Nuphar, Plant Syst. Evol. 239: 187-197.

Padgett D.J., 2007, A monograph of Nuphar (Nymphaeaceae), Rhodora 109(937): 1-95.

Scheider E.L., Williamson P.S., 1993, Nymphaeaceae, [in:] Kubitzki K. (ed.) The Families and Genera of Vascular Plants. II. Flowering Plants. Dicotyledons. Magnoliid, Hamamelid and Caryophyllid Families, Springer, Berlin-Heidelberg-New York-London: 486-493.

Takhtazhian A.L, 1988, Sravnitelnaia anatomiia semian. Tom 2: Dvudolnye, Magnoliidae, Ranunculidae (Comparative anatomy of the families. Vol. 2: Dicotyledones, Magnoliidae, Ranunculidae), Izd. Nauka, Moskva, p. 256 (in Russian).

Tutin T.G., Webb D.A. (eds), 2010 (reprint), Nymphaeaceae, [in:] Tutin T.G., Burges N.A., Chater A.O., Edmondson J.R., Heywood V.H., Moore D.M., Valentine D.H., Walters S.M., Webb D.A. Flora Europaeae. Vol. 1. Psilotaceae to Plantaginaceae. Cambridge Univ. Press, Cambridge, p. 581.

Wiersema J.H., 1988, Reproductive biology of Nymphaea (Nymphaeaceae), Ann. Missouri Bot. Gard. 75: 795-804.

Valceva O.V., Savich E.I., 1965, O razvitii zarodysha u Nymphaea candida Presl i N. tetragona Georgi (On the germ development in Nymphaea candida Presl. and N. tetragona Georgi), Botan. Zhurnal 50(9): 1323-1326 (in Russian).

Yamada T., Imaichi R., Kato M., 2001, Developmental morphology of ovules and seeds of Nymphaeales, Am. J. Bot. 88(6): 963-974.

Zając A., Zając M. (eds), 2001, Nuphar, Nymphaea, [in:] Atlas rozmieszczenia roślin naczyniowych w Polsce (Distribution atlas of vascular plants in Poland), Inst. Bot. UJ, Kraków: 371-372 (in Polish).

Zhou Q., Fu D., 2008, Reproductive morphology of Nuphar (Nymphaeaceae), a member of basal angiosperms, Plant Syst. Evol. 272: 79-96. 